\title{
Traffic Injuries: Peer-educational Prevention: Still the Best Solution?
}

\author{
${ }^{1}$ Phillipe Abreu-Reis, ${ }^{2}$ Lucas de S Benatti, ${ }^{3}$ Geovanna AL de Souza, ${ }^{4}$ Carolina Oldoni, ${ }^{5}$ Pedro A de A Goes, \\ ${ }^{6}$ Ana L Bettega, ${ }^{7}$ Caroline LBD Bosco, ${ }^{8} \mathrm{Jean} \mathrm{R}$ Novais, ${ }^{9}$ Thais Takamura, ${ }^{10}$ Adonis Nasr, ${ }^{11} \mathrm{Flavio} \mathrm{S}$ Tomasich, \\ ${ }^{12}$ Jessica Romanelli, ${ }^{13}$ Iwan A Collaço
}

\begin{abstract}
ABSTRATO
Introdução: Em 2013, 159.152 internações hospitalares foram relacionadas a lesões no trânsito. Considerando todos os tipos de causas externas, as lesões no trânsito constituem uma parcela significativa, representando mais de $20 \%$ das mortes. O objetivo deste estudo é avaliar a percepção das crianças sobre eventos traumáticos quando questionadas por estudantes de medicina, bem como identificar se atividades de extensão universitária em escolas privadas ou públicas têm o mesmo impacto.
\end{abstract}

Métodos: Estudo de coorte comparativa prospectiva com crianças de escolas básicas da cidade de Curitiba-PR. De maio a junho de 2016, foi aplicado um questionário de pré e pós-teste com perguntas sobre questões de segurança no trânsito, questões comportamentais de tráfego e 8 questões de tomada de decisão sobre cenários de tráfego, antes e depois de uma palestra educativa sobre prevenção de lesões no trânsito.

Resultados: Ao comparar os resultados das escolas públicas e privadas entre si, pode-se observar que nas escolas privadas a pontuação média no primeiro teste foi de $77,62 \%$ e de $78,37 \%$ no segundo. No entanto, nas escolas públicas a média foi de $68,75 \%$ no primeiro teste e no segundo a média foi a mesma das escolas privadas, $78,37 \%$. Em suma, a média das escolas públicas teve uma melhora de $14 \%$ em relação ao primeiro teste, com diferença significativa, $p=0,01370$. Enquanto no pré-teste, houve uma pontuação média de 6,21 nas escolas privadas e 5,5 nas públicas, com $p=0,0000013$, no pós-teste, a pontuação média nas escolas privadas e públicas foi de 6,27 , resultando em $p<0,0000001$

Conclusão: Nesta atividade de prevenção com o objetivo de identificar onde poderíamos ter maior impacto, observamos que nas escolas privadas os resultados da intervenção foram inferiores, sendo o impacto da atividade maior nas escolas públicas.

Palavras-chave: Educação Básica, Extensão Universitária, Prevenção, Traumatismos no Trânsito.

\section{ABSTRACT}

Introduction: In 2013, there were 159.152 admissions to hospitals related to traffic injuries. Considering all sorts of external

\footnotetext{
${ }^{1}$ Trauma Surgeon, ${ }^{2-9}$ Student, ${ }^{10,11}$ Professor, ${ }^{12}$ Academic Director, ${ }^{13} \mathrm{HOD}$

${ }^{1-13}$ Department of Surgery, Hospital do Trabalhador, Curitiba, Paraná, Brazil
}

Corresponding Author: Phillipe Abreu-Reis, Trauma Surgeon, Department of Surgery, Hospital do Trabalhador, Curitiba, Paraná, Brazil, e-mail: phillipeareis@gmail.com causes, traffic injuries constitute a significant portion, accounting for more than $20 \%$ of deaths. The aim of this study is to assess children's perception on traumatic events surveyed by medical students as well as identify if the peer-educational in private or public schools have the same impact.

Methods of research: A prospective interventional comparative cohort study with children from a basic school in the city of Curitiba-PR. A survey with a large number of questions on road safety issues, traffic behavioral issue and 8 decision-making questions about traffic scenarios was applied from May to June 2016 , before and after a peer-educational lecture on prevention of traffic injuries.

Results: When comparing the results of public and private schools between themselves, it can be observed that on the private schools the average score on the first exam was of $77.62 \%$ and of $78.37 \%$ on the second one. However on public schools the average was of $68.75 \%$ on the first test and on the second exam the average was the exact same of the private schools result on it, $78.37 \%$. Summing up, the public schools average had an improvement of $14 \%$ compared to the first test, with a significant difference, $p=0.01370$. While on the pre test, there was an average score of 6.21 in private schools and 5.5 in public ones, with $p$ $=0.0000013$, in the post-lecture, the average score on private and public schools was of 6.27 , resulting in $p<0.0000001$.

Conclusion: Our prevention activity aiming to identify where we could have greater impact, resulted on us observing that private schools had lower results and the impact was better in public schools.

Keywords: Basic school, Peer-educational prevention, Traffic injuries, Trauma.

How to cite this article: Abreu-Reis $P$, Benatti LDS, de Souza GAL, Oldoni C, Goes PADA, Bettega AL, Bosco CLBD, Novais JR, Takamura T, Nasr A, Tomasich FS, Romanelli J, Collaço IA. Traffic Injuries: Peer-educational Prevention: Still the Best Solution? Panam J Trauma Crit Care Emerg Surg 2018;7(3):199-203.

\section{Source of support: Nil}

\section{Conflict of interest: None}

\section{INTRODUCTION}

Life expectancy of the population has grown significantly in recent decades due to advances in quality of life and medicine, but there is a significant difference between natural and external causes of death. From 2005 to 2009, external causes were the third biggest cause of death in Brazil (12.57\%), exceeded only by heart diseases and cancer. ${ }^{1}$ 
In 2013, there were 159.152 admissions to hospitals related to traffic injuries. These admissions cost directly $\mathrm{R} \$ 210.750 .485 .00$ to the country. In that same year, there were 43.230 deaths due to traffic injuries, 4.698 of which being of children and adolescents in the range 0 to 19 years old. Still, in the topic of children and teenagers, the mortality of this group drops at a great rate: between 1980 and 2013, deaths from natural causes went from 228,485 to 53,852 , a sharp drop of $76.4 \%$. On the other hand, deaths caused by external causes grew slowly in the same period: from 16.457 in 1980 to 22.041 in 2013; an increase of $33.9 \% .^{2-4}$

Considering all types of external causes (falls, drownings, assaults, etc.), traffic injuries compose a significant percentage of the total of deaths, accounting for more than $20 \%$ of them. ${ }^{2}$ These data show the importance of preventing deaths related to external causes, especially regarding traffic accidents, which should be seen as a real issue of public health.

Trauma deaths are classically described as having a trimodal pattern distribution: Immediate, early and late. Immediate deaths occur seconds to minutes after the injury, and they are usually unpreventable (eg. Apnea due to high spinal injury, or hemorrhage due to great vessel disruption). Early deaths occur minutes to hours after the injury, improvement in ATLS emergency care target these specific patients. Late deaths happen days to weeks after the injury and optimal early management may prevent these. Once $53 \%$ of deaths occur at the first mode of the trimodal distribution of death, these deaths cannot be reduced by a medical care improvement. ${ }^{5}$ Therefore, these important injuries can be reduced by prevention of trauma and one of the best ways to manage this issue is through incorporating preventive measures to the daily routine of basic schools. Therefore, these important injuries can be reduced by the prevention of trauma and one of the best ways to manage this issue is by incorporating preventive measures into the daily routine of basic schools. Children have a greater capability of absorbing knowledge and will potentially spread information throughout their lives. ${ }^{6}$

Academic leagues are groups managed by medical students, from different semesters, under the supervision of professionals linked to educational institutions with the objective of discussing some themes. In addition to classes, research activities and assistance, the incorporation of students is important to the community, through educational activities, prevention, and health promotion. These associations play an important role in medical education, improving knowledge and making the student closer to the community. ${ }^{7}$

A trauma academic league should aim to spread the concepts of "trauma disease". For these reasons, the
The practice of peer-education is the easiest way to establish an effective communication, reflecting in a better understanding of the one who receives the information given by peers. ${ }^{6}$ It is known that in Brazil students from public and private schools have large discrepancies in socioeconomic conditions. These discrepancies make it difficult for public schools students to acquire information. ${ }^{9,10}$

\section{OBJECTIVES}

The aim of this study is to assess children's perception on traumatic events surveyed by medical students as well as to identify if the impact of peer-education is the same in public and private schools, and then to introduce a costeffective peer-education action to be adopted worldwide.

\section{METHODS OF RESEARCH}

A prospective interventional comparative cohort study with children from a basic school in South Brazil. Two schools were chosen; a private one and a public one, in the city of Curitiba-PR. A survey with a large number of questions on road safety issues, traffic behavioral issue and 8 decision-making questions about traffic scenarios were applied by volunteer medical students of Hospital do the Trabalhador/Federal University of Parana, from May to June 2016, before and after a peer-educational lecture on preventing traffic injuries. There were 20 epidemiological questions as well.

The group of researchers developed the peereducational lecture, ranging from basic traffic behavioral skills to complex traffic injuries related to car crashes and their epidemiological data.

Questions were asked before and after the lecture, and the answers of pre and post-lecture were compared. Statistical analysis was performed using the Chi-square for discrete, and the students' $t$-test for continuous variables.

\section{RESULTS}

One hundred ninety-two students took part in the study; 91 girls and 101 boys. One hundred thirtyeight of the total number of students were from private schools, and the remaining 54 studied on public ones as demonstrated in Graph 1. The average age of the students was of 11.78 years old; an average of 11.7 years old on the private schools and 11.98 on the public ones. The median was of 12 years old.

Regarding epidemiological questions, 153 children said they have never been involved in a traffic accident and 39 children revealed to have been in at least one in their lives, $46.15 \%$ of those having experienced more than one traffic accident. 

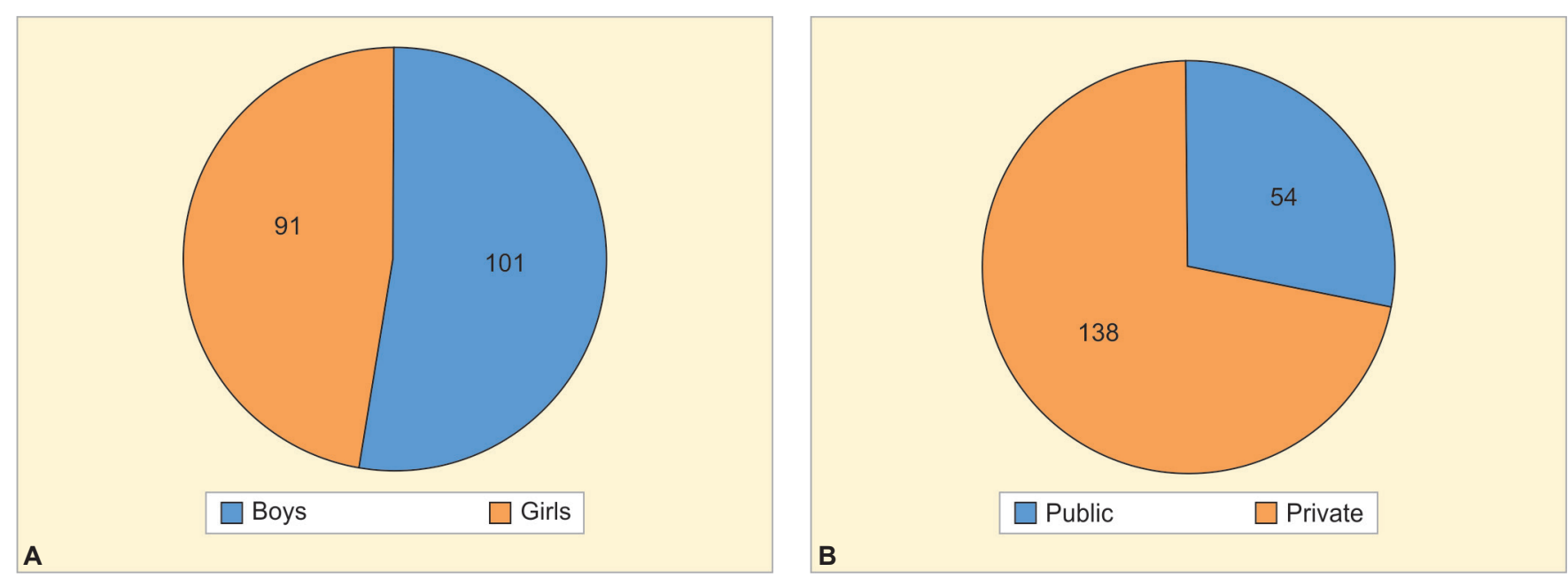

Graphs 1A and B: Epidemiological distribution

The students' behavioral pattern is shown in Graphs 2 and 3 concerning crossing the street in the crosswalk section, only 3 people $(1.53 \%)$ said they have never done that. However, $37.50 \%$ of the interviewed people said they always do, making the remaining $60.41 \%$ the ones who only sometimes cross the street in the crosswalk area. Really similar results were observed on the topic of looking at both sides of the street before crossing it; $1,56 \%$ of the students said they do not check before crossing, while $75 \%$ always check both sides. When asked about crossing the road with an adult by their side, only $39.06 \%$ told they are always accompanied by one, while the other $53.12 \%$ of students only occasionally have an adult by their side.

When asked about walking on the street, 2 children said they never use the sidewalk when moving through the city by foot. On the other hand, 150 students declared to always use it and the remaining 39 people occasionally do it. Still on the topic, 65 people reported to consistently exit the car when they are in on the sidewalk section, while the majority, $64.06 \%$, never or only sometimes leaves the vehicle on the right side of the road, the side where there are not any cars passing through.

Although 84 students do not take the bus as a transportation vehicle, 113 do and $72.56 \%$ of those who do always wait for it to stop completely before leaving it. The remaining people never or only occasionally leave the bus before it stops entirely.

Regarding bicycles and motorcycles, 178 students affirmed to know how to ride a bicycle; 140 of those never ride between cars and 28 students only do it sometimes. The remaining 4 said they always ride between cars. Only 85 people stated they use the motorcycle as transportation.

The 124 students play on the street and $50 \%$ of those are never followed by an adult, while $13.7 \%$ are all the time with an older person by their side when they do.

When asked about cars, one student did not answer the questions and another one said to have never ridden a car. Of the remaining 190 people, only $8.42 \%$ do not use the passenger seat (front seat) when riding one. Driving

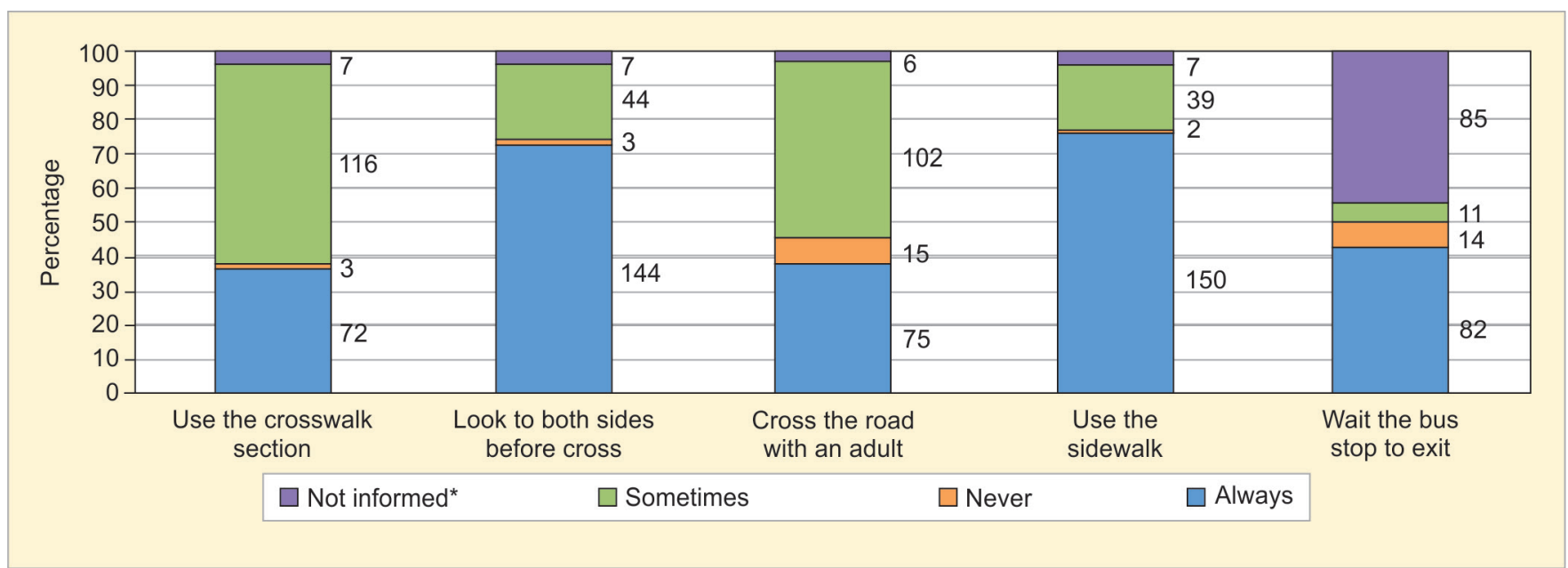

Graph 2: The students' behavioral pattern 


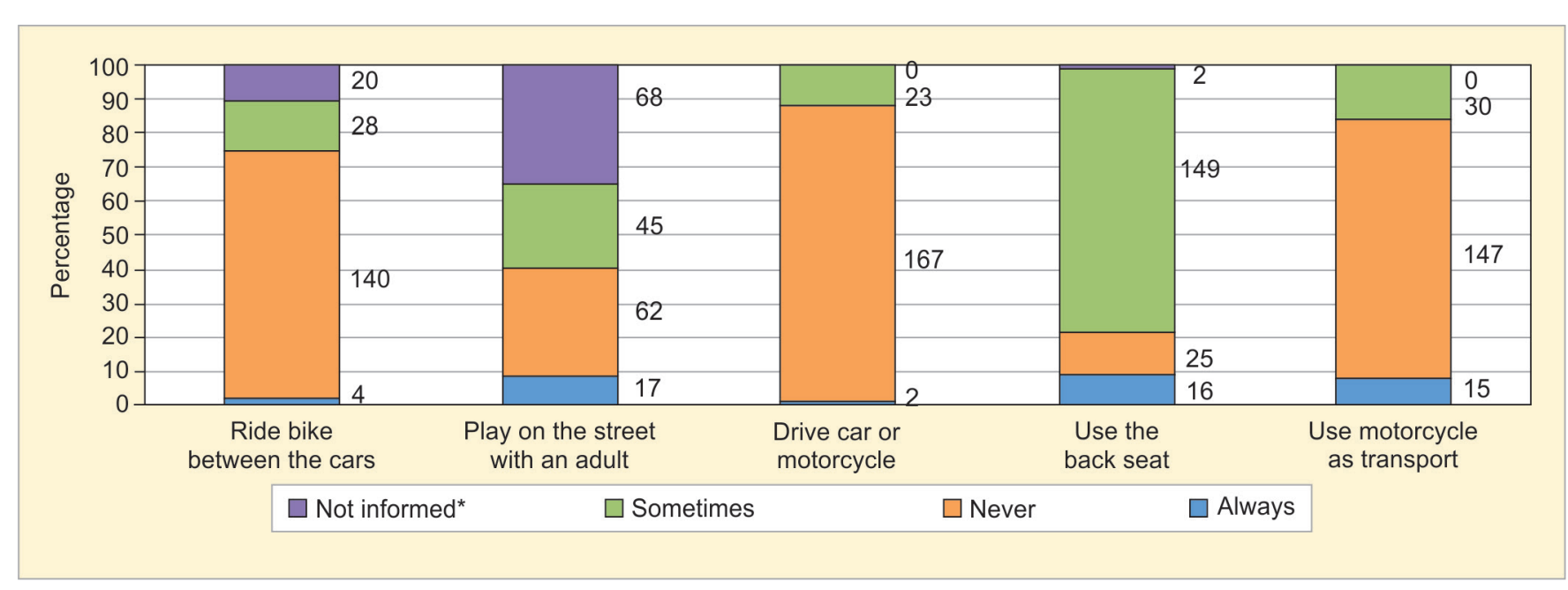

Graph 3: Students' traffic behaviour

cars/motorcycle without having the appropriate age for it was also a question; 167 students specified they've never driven one. However, $13.02 \%$ said they often or always do it.

The knowledge section, which had eight questions about traffic knowledge, resulted in 192 students answering them before the lecture, 138 of which were from private schools and 54 from public ones. The questions after the lecture were answered by 166 people, 54 of which from public schools and 112 from private schools. The average score on the pre-lecture "test" was of $75.01 \%$ and of $78.35 \%$ on the post-lecture test, with a significant difference between them, $\mathrm{p}=0000475$.

When comparing the results between public and private schools, it can be observed that on private schools the average score on the first exam was of $77.62 \%$ and $78.37 \%$ on the second one. However, in public schools, the average was of $68.75 \%$ on the first test and the second exam, the average was the exact same of the private schools result in it, $78.37 \%$. Summing up, the public schools average had an improvement of $14 \%$ compared to the first test, with a significant difference, $\mathrm{p}=0.01370$.

On the pre-lecture questions, there was an average score of 6.21 in private schools and 5.5 in public ones, with $\mathrm{p}=0.0000013$. In the post-lecture questions, the average score on private and public schools was of 6.27, resulting in $\mathrm{p}<0.0000001$. Graph 4 presents comparison statistics.

\section{DISCUSSION}

There are several flaws in the conduct of students on the topic of security and coexistence in traffic; there was a large number of students who had already been involved in a traffic accident $-20 \%$ of them. ${ }^{11}$ This means that even not driving, the majority of the students who are less than 12 years old have already had significant traffic issues, and suffered from it, so there is a great importance to

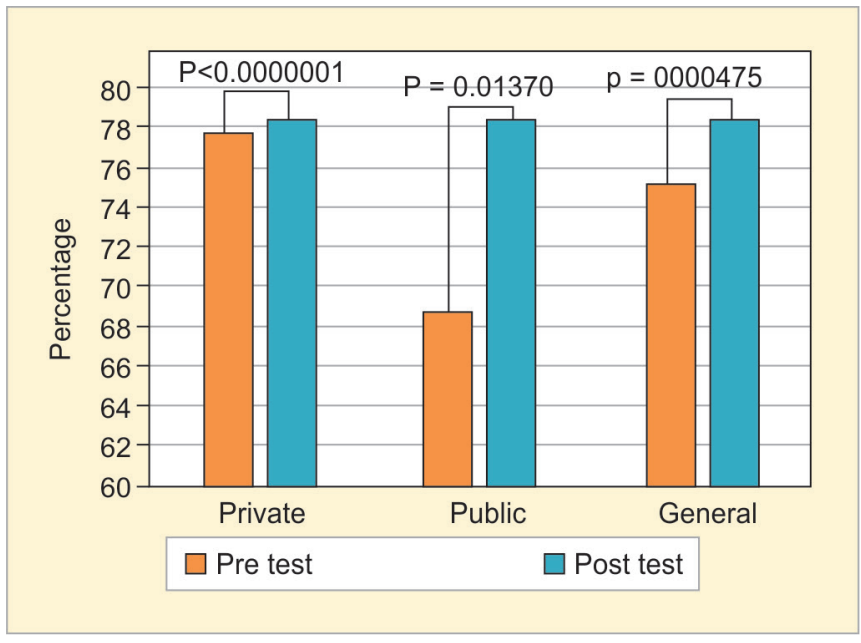

Graph 4: Students' test perfomance

intervening and educating these young people to erase the huge number of traffic incidents in Brazil, that in 2015 had more than 43,000 deaths and 201.00 injuries in the traffic accidents area. ${ }^{12}$

With only $35 \%$ of children crossing the street in the correct area, nearly $30 \%$ stating that they never or only sometimes cross the street looking to both sides of it, less than $40 \%$ crossing it accompanied by an adult, and a fifth who walk in the streets (no pavement) there is an observed modifiable risk that these people are more likely to be involved in accidents on roads. These are reasons that explain why more than $10 \%$ of deaths due to traffic accidents are of children and teenagers. ${ }^{2}$ Another reported issue is the lack of education in relation to laws, where in Brazil, according to Law 9.503/1997, people are only able to drive and have the National driver's license ${ }^{*}$ $(\mathrm{CNH})$ when they are over 18 years old and are only able to ride in the front seat of the car when they are 10. Because all students in the study were more than 10 years, the expected result was that the vast majority used the front seat of the car, however, what draws attention is that almost $15 \%$ of the studied people ride a car or a bike 
between cars when they are not allowed to according to the country's legislation system.

Just like mentioned before, the issues observed by a large number of children riding bikes between cars and half of the children playing in the street without adult supervision, show the importance of academic leagues' presence in the population. It is crucial to show the people what is right and what is wrong, as well as what to teach people how to fix problems in traffic. That has to be done by performing activities with children and teenagers and sharing knowledge for a better future of the nation. As suggested by the ATLS, 53\% of deaths can be avoided with prevention. ${ }^{13}$

Although there was an improvement in all of the students' knowledge, the end result was much more significant in students of public schools. These had an increase of almost $15 \%$ correct questions on the postlecture test. The impact of talking about prevention in public schools was substantially higher. This performance difference seems to be explained by the fact that private school students already have higher prior knowledge compared to public school students. That fact is a reflection of the discrepancy that exists between public and private schools, since public schools in Brazil are in need of better conditions and information, and have a very poor basic education. ${ }^{14,15}$

\section{CONCLUSION}

Students from public schools had lower outcomes in prevention knowledge background when compared to students from private schools. After peer educational activities, every child can achieve a good result and be prepared for real life. Prevention can raise people awareness of health problems and reduceinjuries in thenear future.

\section{REFERENCES}

1. Mortalidade - Brasil [Internet]. [cited 2018 Aug 5]. Available from: http://tabnet.datasus.gov.br/cgi/tabcgi.exe?sim/cnv/ obt10uf.def.
2. Óbitos por Causas Externas-Brasil [Internet]. [cited 2018 Aug 5]. Available from: http://tabnet.datasus.gov.br/cgi/tabcgi. exe?sim/cnv/ext10uf.def.

3. Morbidade Hospitalar do SUS - por local de internação - Notas Técnicas [Internet]. [cited 2018 Aug 4]. Available from: http:// tabnet.datasus.gov.br/cgi/sih/midescr.htm\#origem.

4. WHO | World Health Statistics. WHO [Internet]. 2018 [cited 2018 Aug 5]; Available from: http://www.who.int/gho/publications/world_health_statistics/en/.

5. Baker CC, Oppenheimer L, Stephens B, Lewis FR, Trunkey DD. Epidemiology of trauma deaths. The American Journal of Surgery. 1980 Jul 1;140(1):144-150.

6. Houston M, Cassabaum V, Matzick S, Rapstine T, Terry S, Uribe $\mathrm{P}$, et al. Teen traffic safety campaign: competition is the key. Journal of Trauma and Acute Care Surgery. 2010 Mar 1;68(3):511-514.

7. Peres CM, Andrade A dos S, Garcia SB. Atividade extracurriculares: Multiplicidade e Diferenciação Necessárias ao Currículo. Revista Brasileira de Educação Médica. 2005;29(2):203-211.

8. Nasr A, Talini C, Strack Neves GC, Augusto Collaco I, Fortunato Domingos M, de Abreu Reis PGT. Prevencao ao Trauma e Atendimento de Qualidade: Uma Decada de Liga Academica do Trauma no Hospital do Trabalhador - UFPR (Curitiba-PR, Brasil). Ivatury Richmond RR, editor. Panamerican Journal of Trauma, Critical Care \& Emergency Surgery [Internet]. Jaypee Brothers Medical Publishing; 2012 May;1:127-130.

9. PISA 2012 Results in Focus. 2012;

10. Seguras V. Estatísticas Nacionais de Acidentes de Trânsito. http://www. viasseguras. com/layout/set/print/ os_acidentes/estatisticas/estatisticas_nacionais. Acesso em. 2014;10(01):2014.

11. Ministerio da saúde:Vigilância de violências e acidentes [Internet]. Available from: www.saude.gov.br/editora

12. Estatísticas nacionais de acidentes de trânsito [Internet]. [cited 2018 Aug 5]. Available from: http://www.vias-seguras.com/ layout/set/print/os_acidentes/estatisticas/estatisticas_nacionais

13. Kendrick D, Coupland C, Aj M, Mulvaney C, Simpson J, Smith $S$, et al. Home safety education and provision of safety equipment for injury prevention (Review). Evid Based Child Health. 2013 May;8(3):761-939.

14. Sampaio B, Guimarães J. Diferenças de eficiência entre ensino público e privado no Brasil. Economia Aplicada. 2009 Mar;13(1):45-68.

15. Albernaz Â, Ferreira FH, Franco C. Qualidade e eqüidade na educação fundamental brasileira. Texto para discussão; 2002. 